\title{
Public Expenditure Management in Indonesia: Islamic Economic Review on State Budget 2017
}

\section{Aan Jaelani}

\author{
State Islamic Institute Syekh Nurjati (IAIN Syekh Nurjati Cirebon); \\ Correspondence: aan_jaelani@syekhnurjati.ac.id; Tel.: +62-821-1929-3321
}

\begin{abstract}
This paper discusses the management of public expenditures in Indonesia in State Budget 2017. The data collected from fiscal policy documents, especially about government spending plans in 2017, and then be reviewed by policy analysis, the theory of public expenditures, and the theory of public goods, and compared with the theory of public expenditure in Islamic economics. Public expenditure management in Indonesia has implemented a distribution system that divided public expenditure for central government expenditures, transfers to the regions, and the village fund. In terms of fiscal policy, public expenditure priorities to support the achievement of sustainable economic growth, job creation, poverty reduction, and the reduction of gaps in the welfare of the whole community. In Islamic economics, public expenditure is used to meet the needs of the community based on the principles of general interest derived from the shari'a. Public expenditure on Indonesia's government as an effective tool to divert economic resources and increase the income of society as a whole, and focused on the embodiment of the people's welfare.
\end{abstract}

Keywords: State budget; fiscal policy; public expenditure; Islamic Economic

\section{Introduction}

The government's role is increasing almost in all economic system. Increasing the role of government, the greater public expenditure in proportion to national income. Public expenditure in real terms can be used as an indicator of the size of government activities financed by the government. The bigger and more activities, the greater the public expenditure is concerned. But it should be realized that the proportion of public expenditure to gross national income is a very rough measure of the activity or the role of government in a form of economy.

Therefore, public expenditure related to the implementation of the budget system. Public revenue in modern secular states generally consists of two types, namely the current budget and the capital budget. Current budget is used to meet the expenditure on aspects of civil administration, defense, the cost of servicing the debt, and more, while the capital budget is used for the construction of infrastructure, educational institutions, health facilities, telecommunications, defense projects, dams, canals, power plants, highways, and train.

The economic function is required for any economic system, not only to provide public goods but also to allocate goods production and consumption, in addition to improving the distribution of income, maintain national stability, including political stability, as well as economic growth accelerates.

Every member of the public wish to meet their needs, so it is necessary to the security and justice that can be facilitated by the state, one of which uses goods and services in a variety of forms, including money, the economic resources that include human resources, natural, capital, and so on. In this case, the management of public expenditure required to meet those objectives.

In the State Budget 2017 in Indonesia, the public revenue target set at Rp1.750,3 trillion, consisting of; (1) tax of Rp1.498,9triliun; (2) non-tax revenues (non-tax) of Rp250,0 trillion, and (3) grant receipt of Rp1.3 trillion. On the expenditure side agreed at Rp2.080,5 trillion, consisting of central government spending is Rp1.315,5 trillion, and transfers to regional and rural funds amounting Rp764,9 trillion. Central government expenditures consist of expenditures Ministry/Agency for Rp763,6 trillion and expenditures Non Ministry/Agency for Rp551,9 trillion. 
As for the deficit, the amount is still within the limits in accordance with the legislation, which amounted Rp330,2 billion or 2.41 percent of the Gross Domestic Product (GDP). The budget deficit in 2017 is planned to be financed with a budget of Rp330,2 billion financing.

The general policy of public expenditure of Indonesia in the state budget 2017 will be directed to support the achievement of development goals, including through efforts to spur economic growth and uneven quality, reduce poverty, reduce unemployment and control inflation. In addition, the government will also continue to sharpen the efficiency and effectiveness of central government expenditure in order to improve the quality of public expenditure.

The utilization of central government expenditure is also aimed at improving the quality of spending prolific and priority among other efforts are focused on continuing efficiency policy subsidies are better targeted, improve the quality and effectiveness of social protection programs, such as Card Healthy Indonesia, the Family Hope Program, Scholarship Aim Mission etc., improve service effectiveness and sustainability of the National Programme on Social Security System, strengthening bureaucratic reform, among others by maintaining the level of welfare of the state apparatus, and strengthen certainty and enforcement legal, defense and security stability, as well as politics and democracy. As for the allocation of central government expenditure in the state budget, 2017 amounted to Rp1.315.526,1 billion (9.5 percent of GDP). The allocation of central government expenditure in the state budget 2017 will be used primarily to fund development programs (Ministry of Finance, 2016).

In the field of infrastructure, based on the Global Competitiveness Report 2015-2016, overall infrastructure quality Indonesia ranks 81 out of 140 countries. Meanwhile, according to the UNDP report, Indonesia's Human Development Index 2015 ranks 110 of 187 countries. Therefore, in order to spur accelerated development, the government needs to implement more expansionary spending policy in the state budget, but keep it within the fiscal sustainability.

The government absolutely play a part in any form or economic system, not only to provide public goods but also to allocate goods production and consumer goods, in addition to improving the distribution of income, maintain national stability, including political stability, as well as economic growth accelerates. Therefore, the government requires many sources of income in order to carry out its role to create prosperity for the people.

In the Islamic economic system, the government has an obligation to create a welfare of society through its stated policies. Even the role of the state is to maintain the implementation of religious teachings and prosperity of the people. In other words, the welfare of society embodied in the form of public expenditure gain legitimacy in the shariah.

This paper analyzes the management of public expenditure, the purpose of public expenditure, and shopping system the Indonesian government in States Budget 2017, and reviewing comparative with the concept of public expenditure in Islamic economics, so it can be known aspects of the function and practice of public expenditure aimed at creating prosperity community.

\section{Literature Review}

\subsection{Theory of Public Expenditure}

To understand the development of public expenditure, it can be analyzed through the theory of macro and micro theory. Public expenditure for the purchase of goods and services is an injection to the economy that has an impact on economic growth. Public expenditure is an exogenous expenditure which is determined by the extent of the availability of government budgets derived from taxation. Public expenditure efforts aimed at the provision of infrastructure such as public facilities, as well as in the form of direct transfer aimed at income distribution and address poverty.

Macro theory of the development of public expenditure can be analyzed with the model of development of Rostow and Musgrave, Wagner law on the development of government activities, and Peacock and Wiseman theory. These theories motivated by the development of ever-increasing public expenditure due to increased activity of the government in the economic system. According to Foster \& Fozzard (2000), the role of government is increasing causing the proportion of public expenditure to national income increases. Public expenditure in real terms can be used as an indicator for government activities are financed by the government itself. However, the proportion 
of public expenditure to gross national income is a very rough measure of the government's activities in a form of economy.

Table 1. Theory of Development of Public Expenditure

\begin{tabular}{|c|c|c|c|}
\hline No & $\begin{array}{l}\text { Theories/Mod } \\
\text { els }\end{array}$ & Desciption & References \\
\hline 1 & $\begin{array}{l}\text { Model } \\
\text { development } \\
\text { of Rostow } \\
\text { and } \\
\text { Musgrave }\end{array}$ & $\begin{array}{l}\text { According to Rostow, the process of economic } \\
\text { development can be divided into five stages: the } \\
\text { traditional society, the preconditions for taking off, the } \\
\text { take-off, the drive to maturity, and the age of high } \\
\text { mass-consumption. Basic differences in stages of } \\
\text { economic development that is characteristic of changes } \\
\text { in economic conditions, social and political situation in } \\
\text { the community. } \\
\text { According to Musgrave, a process of development will } \\
\text { be characterized by the presence of private investment } \\
\text { as a percentage of GNP and the greater the percentage } \\
\text { of government investment as a percentage of GNP will } \\
\text { be smaller. } \\
\text { Musgrave Rostow development model and provides } \\
\text { the basic framework for the increase in government } \\
\text { spending in line with the government's role is even } \\
\text { greater. Although this theory was developed from the } \\
\text { experience of economic development in many } \\
\text { countries, but there is a lack of clarity associated with } \\
\text { the ongoing economic pertumbahan in phases or } \\
\text { stages take place simultaneously and concurrently. }\end{array}$ & $\begin{array}{l}\text { Musgrave \& } \\
\text { Peacock (1958) } \\
\text { Buchanan \& } \\
\text { Musgrave (1999) } \\
\text { Musgrave (1959) }\end{array}$ \\
\hline 2 & $\begin{array}{l}\text { Wagner's } \\
\text { Law on the } \\
\text { development } \\
\text { of } \\
\text { government } \\
\text { activities }\end{array}$ & $\begin{array}{l}\text { The development expenditure for government } \\
\text { activities is increasing. Wagner calls this condition as } \\
\text { the "law of ever increasing state activities, or according } \\
\text { to Musgrave, called the" law of growing public } \\
\text { expenditures". This increase lies in the activities and } \\
\text { needs of the government related to the duties and } \\
\text { functions of government, the use of economic } \\
\text { resources by the government, including government } \\
\text { spending. } \\
\text { Wagner's Law shows that the increasing activities of } \\
\text { the government, despite the increasing needs of } \\
\text { government, and the ever increasing state } \\
\text { expenditures. } \\
\text { Wagner's law assumes that in an economy when per } \\
\text { capita income increases, the relative government } \\
\text { spending will increase. Wagner's law is based on } \\
\text { empirical observation of the developed countries, but } \\
\text { the law provides a basis will the emergence of market } \\
\text { failure and externalities. }\end{array}$ & $\begin{array}{l}\text { Wagner \& } \\
\text { Weber (1977) } \\
\text { Musgrave (1959) } \\
\text { Backhaus \& } \\
\text { Wagner (1987) } \\
\text { Kayaalp (2004) } \\
\text { Peacock \& } \\
\text { Wiseman (1967) }\end{array}$ \\
\hline 3 & $\begin{array}{l}\text { Theory } \\
\text { Peacock and } \\
\text { Wiseman }\end{array}$ & $\begin{array}{l}\text { Peacock and Wiseman's theory is based on empirical } \\
\text { research with emphasis pattern development time and } \\
\text { not be continious government spending growth, but } \\
\text { rather like a staircase. Both are named with the term } \\
\text { "steplike". } \\
\text { The government is always trying to expand public }\end{array}$ & $\begin{array}{l}\text { Peacock \& } \\
\text { Wiseman (1967) } \\
\text { Atkinson \& } \\
\text { Stiglitz (1980) }\end{array}$ \\
\hline
\end{tabular}


spending while not like paying taxes to finance

Bird (2001)

growing government spending are growing. Peacock and Wiseman hypothesis theory formed the basis of the theory of voting.

Buchanan \&

This theory also explained that society has a tolerance Musgrave (1999) level of the tax, which is a level where people can understand the magnitude of the tax levy required by the government to finance government spending. In this case, the cause of economic development tax collection increased even though tax rates have not changed; and increased tax revenues caused government spending also increased.

\subsection{Theory of Public Goods}

One role of government is quite important in view Rossen \& Gayer (2008) is making decisions regarding the allocation of economic resources to produce public goods. In this case, practice the socialist economic system largely private goods produced by the government, while the capitalist economic system implemented most public goods produced by the private sector.

In outlining the allocation of economic resources that is optimum for private goods and public goods can not be separated from the cost of production. The private sector has various sources of funds to carry out the production, ie by borrowing from banks, selling shares or of the profits that are not distributed to shareholders (retained earnings). The government also has other sources of funding to implement ativitasnya, for example by foreign loans, by printing money or by levying a tax.

There are several theories that analyze public goods in terms of the allocation of economic resources, the theory of Pigau, the theory of Bowen, the theory of Eric Lindahl, the theory of Samuelson, and theory of the budget.

Table 2. Theory of Public Goods

\begin{tabular}{|c|c|c|c|}
\hline No & $\begin{array}{l}\text { Theories/ } \\
\text { Models }\end{array}$ & Desciption & References \\
\hline 1 & $\begin{array}{l}\text { Theory of } \\
\text { Pigau }\end{array}$ & $\begin{array}{l}\text { According to Pigau, public goods should be provided to the } \\
\text { extent that marginal satisfaction on public goods equal to } \\
\text { dissatisfaction marginal (marginal disutility) will tax levied to } \\
\text { finance government programs or to provide public goods. } \\
\text { Pigau theory has a weakness in explaining the public good } \\
\text { because it is based on a sense of dissatisfaction marginal } \\
\text { improvement of the tax and marginal sense of satisfaction will } \\
\text { be a public good, while satisfaction and dissatisfaction are } \\
\text { something that can not be quantified due to its ordinal. }\end{array}$ & Pigau (1920) \\
\hline 2 & $\begin{array}{l}\text { Theory of } \\
\text { Bowen }\end{array}$ & $\begin{array}{l}\text { Bowen theory can be explained by making a distinction } \\
\text { between private goods and public goods. Private goods are } \\
\text { goods that have the properties of an exception, so that the } \\
\text { owner of an item can exclude others from the benefits of such } \\
\text { goods, such as shoes. } \\
\text { Bowen's theory has flaws by using analysis of demand and } \\
\text { supply. This weakness lies in the principle of public goods that } \\
\text { can not be enforced exclusion so that people do not want to } \\
\text { use the pleasure (preference) will be the item that makes the } \\
\text { demand curve does not exist. }\end{array}$ & $\begin{array}{l}\text { Rossen \& } \\
\text { Gayer (2008) }\end{array}$ \\
\hline 3 & $\begin{array}{l}\text { Theory of } \\
\text { Erick }\end{array}$ & $\begin{array}{l}\text { Erick Lindahl theory is similar to Bowen's theory, only the } \\
\text { payment of each consumer is not in the form of absolute price, }\end{array}$ & $\begin{array}{l}\text { Musgrave \& } \\
\text { Peacock }\end{array}$ \\
\hline
\end{tabular}




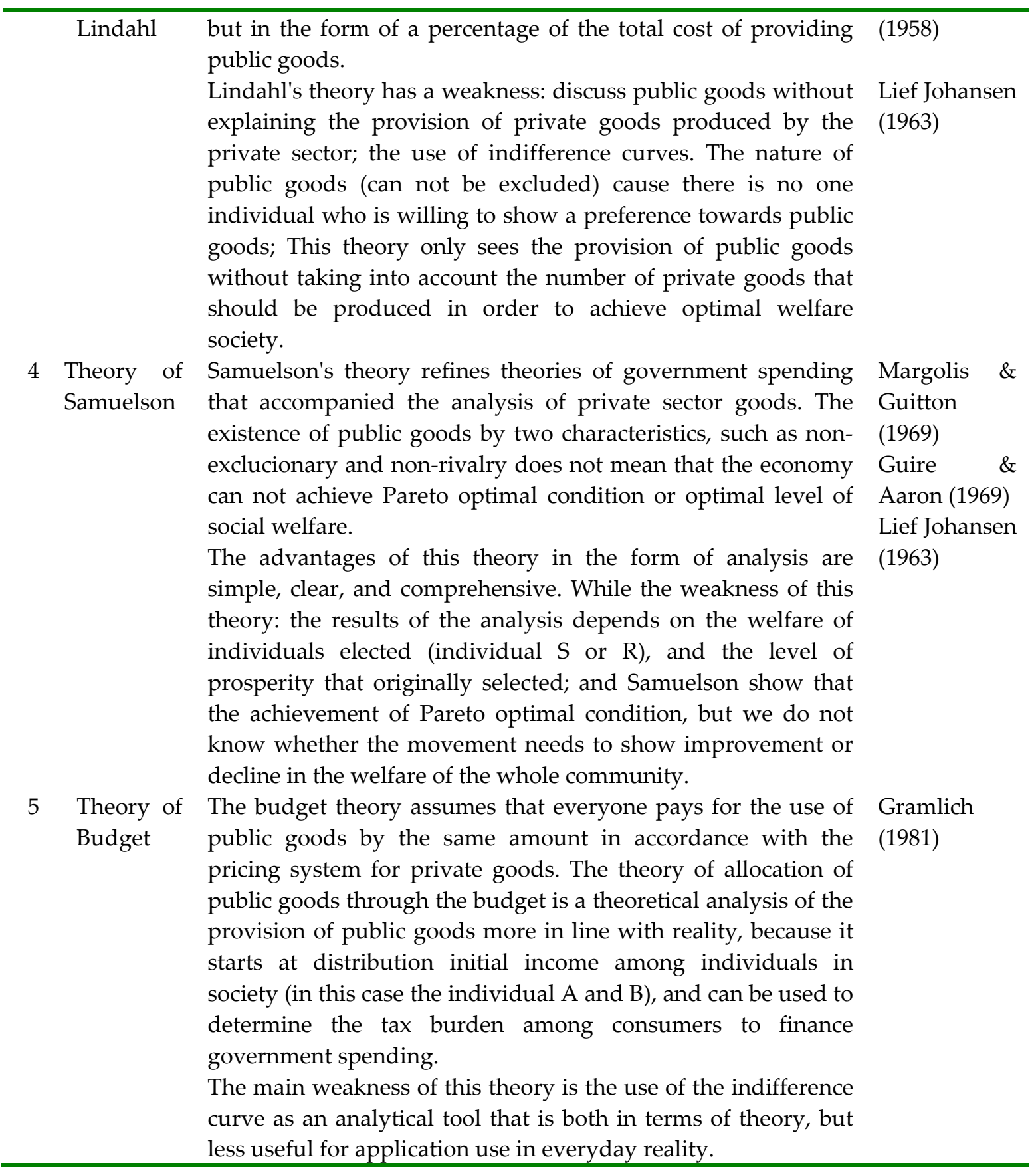

Some public goods theory has been put forward to the use of the demand curve and or the indifference curve which in practice can not be measured empirically. Therefore, economic theory is considered unable to solve the issue with the allocation of economic resources to produce private goods and public goods empirically, and the solution must be implemented with the voting process is usually done in the political process. However, polls also can not provide a very satisfactory solution except in a society where their preferences are identical so as to achieve the result by acclamation.

Mawardi (1996), Shafi'i jurists and statesman Abbasid period, giving particular idea associated with public goods in the form of protected land (al-hima) and public facilities (al-arfaq). Al-hima is a regulation on the ground that is prohibited to be processed and a person so that he remains a region which may be used for anyone, where pasture and grazing animals. As for public facilities such as public facilities and infrastructure such as a seat on the market, on a side street, in the suburbs, and the resting place for guests. The government's task, among others, provide a facility that can maintain the safety, preserve water supplies, and provide an opportunity for people to have it. 
Some remarks from Mawardi above opinion related to public goods, among others; first, the government's role is dominant to ensure the availability of goods or facilities needed by many people, as well as give the prohibition for anyone to have it; second, public goods, including also the needs of society which is the responsibility of the government to fulfill, such as the implementation of religious teachings and harmonization of religious, public security, education, national defense, and so forth; third, the government appointed officers for the maintenance of public facilities or the need for a national, eg hire scholars who provide teaching or prayer leader; and fourth, ensuring the creation of prosperity for the fulfillment of the needs of living through income distribution in a fair and equitable public.

\section{Methods}

In this study, management of public expenditure in Indonesia on the State Budget 2017 will be analyzed in a comprehensive literature review. Data gathered from source documents of the Ministry of Finance of the Republic of Indonesia and the information in the form of draft budget in response to the determination dated August 18, 2016, until the enactment of the Law of the Republic of Indonesia on State Budget 2017 on November 17, 2016. These data are reviewed using data analysis policies of management public expenditure in Indonesia, theories of public expenditures and public goods, and then be reviewed by the comparative analysis of public expenditures in Islamic economics, so that the conclusion of the study.

\section{Results}

\subsection{Principles of Public Expenditure Management}

In the Law of the Republic of Indonesia Number 18 The year 2016 on the State Budget 2017, noted that the state budget is the obligation of the central government which is recognized as a reduction to net worth consists of central government expenditure and transfer funds to the regions and villages. Central government expenditure by function is central government expenditure that is used to perform the function of public services, defense function, the function of order and security, economic function, environmental function, the function of housing and public facilities, health function, the function of tourism, religious functions, educational functions, and social protection function.

The central government expenditure by organizations is of central government expenditure allocated to the state ministries or agencies and the state general treasury budget section. Central government expenditure on the program is of central government expenditure allocated to achieve specific results in the budget of the state ministries or agencies and the state general treasurer, the budget (Ministry of Finance, 2016).

Expenditure policy Ministry/Agency which are based on the direction of fiscal policy and the Government Work Plan 2017 directed among others to improve the performance of government officials, supported the policy of reform bureaucracy and maintain the welfare of the state apparatus, continuing efficiency policies and sharpening shopping nonoperasional in ministries/institutions while maintaining the quality of service to the community, to continue and strengthen the construction of infrastructure and connectivity to improve the quality of development, strengthen the implementation of priority programs in education, health, sustainable agriculture and energy, maritime and marine, as well as tourism and industry, support law enforcement (handling case) as well as the stability of defense and security (defense equipment and the prevention of terrorism), and support the improvement of the quality of democracy and the development of political life.

In line with efforts to improve the quality of spending, spending policies Ministry or Agency in 2017 will be directed to support these efforts through improvement of the quality of budgetary planning, improving the quality of the budget is not only focused in the routine but start resultsoriented in line with the arrangement of architecture and Information performance, in the form of editorial improvement or formulation of performance targets (output) in order to improve the quality of implementation of performance based budgeting, monitoring and evaluation of budget management. 
In the Islamic economy, the government should guarantee the basic needs and the equitable distribution of income, because the state was formed to carry out various tasks collectively. Governments have the tools and resources, including financial, to provide this assurance. The design of the overall economic development can not be left to the market mechanism because the market had failures and imperfections. The government is expected to make planning and overseeing the course of economic development.

The government must implement the entire project to improve the welfare of the people. This issue is very important as proposed by Musgrave and Musgrave (1987) that the difficulty lies in the policy in deciding the type and nature of the social good which is filled on a priority basis and how much certain consumers are asked to give a cost. It must be decided through a political process. Voters can decide through their vote choice. Actually, the demands on public needs through the political process is the concept of modern life and financial mechanisms that systematically.

The government must decide the implementation of development projects based on the needs of the public. Abu Yusuf (1979) asserts that if the focus of the tax collection directed at areas of land that can not be planted, where the drains can be found again, then cleaned and repaired, so that the water channels to irrigate the area was planted and can increase farmers' income and government, all charges must be borne by the state treasury. In this case, the public can ask the government to meet certain types of welfare projects.

In this case, Mawardi (1996) confirms that the government will meet the needs of the public nature of social obligations. Thus, the public needs to be met based on the priority scale public or recommendation public authorities based on common interests, or because of its nature as a social obligation. Actually, the procurement needs of the public based on the public interest and social obligations as a model of Islamic finance policy.

Mawardi (1996) also confirmed that the expenditure can be analyzed as follows: "any decline in public wealth is to increase the wealth of the country, and any decrease in the wealth of the country is the increase in public wealth. In addition, government spending and taxation is an effective tool to divert economic resources." The statement also suggests that public spending will increase the income of society as a whole.

State expenditures also used to support the market sector that had a role in the economic growth through the maintenance and preservation as well as the creation of social overheads. This will lead to a decrease in all areas in terms of production costs and efficiency improvements, which will consequently increase production and increase profit. The investment community will also be able to develop industries, such as mining and irrigation, also he can create the infrastructure, which means setting up a base of solid growth.

In addition, the existence of state expenditure is used as a tool to achieve economic stability and to increase production and so forth as described above, the goal is to achieve economic growth and development. Although for developed countries and for less developed countries and differ in priorities. One of the ways in which state spending effect on the rate of economic growth is their ability to work, willingness and ability of the people to save and invest the people. An obvious influence will depend on the shape and the amount of state spending is appropriate to the scope. In other words, state spending is only one or only a part of the economic policy which may be run by a state.

Another phenomenon indicates that the market mechanism is one of the causes of inequality of income and welfare in the society of a country. Inequality or differences in income and well-being not only appear in the form of economic and social injustice but also change the pattern of production and employment. An attempt to minimize the differences mentioned above will be able to support the achievement of economic stability. While stability contained in the economic life would be useful for economic growth. With the creation of the state above, it will have a good influence on the investment climate. The above considerations are also intended to achieve equitable distribution of income and wealth are balanced. State spending is one of the usual way taken to create the conditions.

Syatibi (1995) provides another criterion for public expenditure. The objectives of shariah must be protected to improve the welfare of the community. Therefore, the public interest includes three 
categories, namely primary (dharuriyah), secondary (hajiyah), and recommendation (tahsiniyah). Syatibi (1995) assess that the objectives of shariah can be specified operationally by lowering the practical aspects of the five dimensions, namely the function of religion, the function of basic needs (nafs), the function of education ('aql), durability and function family empowerment (nasl), and the functionof economic (mal). Classification of the public interest indicates that the state budget is managed to achieve the objectives of shariah that focus on the public welfare or happiness in the world and the hereafter.

\subsection{Purposes of Public Expenditure in States Budget 2017}

The preparation of the state budget in 2017, in addition to the macro economic assumptions, are also based on the principal of fiscal policy, which this year carries the theme of "strengthening the fiscal management to increase competitiveness and accelerate economic growth sustainably and fair". In line with this theme, the fiscal policy in 2017 will be directed to support the achievement of sustainable economic growth, job creation, poverty reduction, and the reduction of inequality, which in turn leads to improved welfare for the whole society.

According to the classification functions, allocation of central government expenditure broken down into 11 functions that describe the task of the government in implementing service functions and governance in order to achieve national development goals. In the 2017 draft budget, the allocation of central government expenditure by the function is the largest public service function, which amounted to 26.2 percent of total central government expenditure, the remaining 73.8 percent is spread on the functions of the other. The amount of the allocation for public service function reflects the primary function of government to continuously improve the quality of services to the public (Ministry of Finance, 2016).

The development of the central government budget allocation by function in the years 20162017 are presented in the following table.

Table 3. The Development of Central Government Expenditure by Function (trillion rupiahs)

\begin{tabular}{clcc}
\hline No & Function & $\mathbf{2 0 1 5}$ & $\mathbf{2 0 1 6}$ \\
\hline $\mathbf{1}$ & Public Service & 624,5 & 322,6 \\
$\mathbf{2}$ & Defense & 105,9 & 109,0 \\
$\mathbf{3}$ & Order \& Security & 52,9 & 122,9 \\
$\mathbf{4}$ & Economy & 177,1 & 331,0 \\
$\mathbf{5}$ & Environmental Protection & 9,9 & 11,0 \\
$\mathbf{6}$ & Housing \& Public Facilities & 17,0 & 34,3 \\
$\mathbf{7}$ & Healts & 23,2 & 66,1 \\
$\mathbf{8}$ & Tourism & 3,2 & 5,9 \\
$\mathbf{9}$ & Religion & 5,1 & 9,8 \\
$\mathbf{1 0}$ & Education & 143,6 & 143,3 \\
$\mathbf{1 1}$ & Social Protection & 20,9 & 150,8 \\
& $\quad$ Total & $\mathbf{1 . 1 8 3 , 3}$ & $\mathbf{1 . 3 0 6 , 7}$ \\
\hline
\end{tabular}

In a capitalist system that embraces the free economy, market mechanisms, and private ownership of the goods and services, such as initiated by Adam Smith (in Soepangat \& Gaol, 1991), one of the pioneers of capitalism, asserted that the role of government in public spending are grouped into four kinds, namely: first, the expense of defense; to protect the public (defense function); second, the expense of justice; to create justice; third, the expense of public works and public of institutions; to establish and maintain jobs and public institutions; and fourth, the expense of supporting the dignity of the sovereign; to help increase the dignity of the state.

The idea of Adam Smith showed the role of economic freedom in creating the prosperity of society, so it takes's security, law and order, economic infrastructure, and so forth. However, the weaknesses of the idea lie in the different economic power in society, different occasions, even less expensive if there are unfair competition and war-free liberalism. 
For Mawardi (1983), ownership of property by economic agents should be obtained based on the rights and status. God forbid economic action by way of vanity. If so, all transactions in economic activity that contains elements of injustice are forbidden in Islam, including dishonest competition, and the freedom of the individual in obtaining the treasure. Therefore, to create justice and prosperity of society, the role of government in distributing financial required to meet basic economic needs.

In this case, Mawardi quite meticulous in terms of distribution of wealth by public officials and the recipients, along with proof of receipt. This is in order to avoid mistakes wealth distribution to those who are not entitled and prevent disputes with those eligible for but did not receive properly.

\subsection{System of States Budget for Financial Reform in Islamic Economic}

Classification of state expenditure by function, such as the Government of Indonesia, aims to illustrate various aspects of governance in order to provide public services. Implementation of budget classification by function also contribute positively to the efforts of the government in order to sharpen the budget allocation to the various priority activities that provide greater multiplier effect and sustainable form of economic growth, expansion of employment, and poverty reduction.

In other circumstances, where the community's economy experiencing financial crisis affecting the country as a result of revenue sources especially taxes slumped along with the decline in economic activity, the obligations of the switch to the Muslims. For example, the economic crisis led to people falling into poverty, then they are not subject to either the jizya tax or tax burden on Muslims, otherwise, they've given assistance by the state with the charge taken from the rich Muslims. As for the political, Siddiqi (1962) states that the fiscal policy conducted by the government no other in order to meet the public interest. In this context, the government has sought to distribute wealth fairly and equitably.

In managing the budget, Biyuni (1983) states that the budget managers are not allowed to excess, reduced, or corrupted in public expenditure resulting social disadvantage. For this purpose, budget management is done by the principle of efficient, effective, accountable and transparent.

Efficiently managing the budget will be illustrated through public expenditure based on the government's budget plan has been prepared and the correct method. Therefore, Mawardi (1983) explains that the treasury should not be in deficit, used disproportionately, and does not contain elements of interest, except when used in accordance with the needs that have been previously budgeted. In the management of public expenditure, the government should consider the amount of the available budget. Because of this, public expenditure is wasteful or not in accordance with the budget plan could lead to government cash deficits that could harm the country's finances.

In the Islamic economic system, public expenditure has a welfare function as a form of religious duty. Kahf (2001) explains that Islam puts public expenditure as an important part of the tasks of government. Although the Koran does not regulate in detail the rules relating to public expenditure, but the Prophet Muhammad has been practicing with the use of state property in accordance with the regulations set to spend treasure is none other than to create public welfare. Historically, Kahf (2001) states that public expenditure is the responsibility of the government to meet the needs of growing communities in the field of defense, homeland security, the security of the border areas, and another spending for the community.

Shiddieqy (1992) states that there are three categories of public expenditure. First, public expenditure for tasks explicitly specified by shariah or government regulations, namely defense, legislation, order, justice, prosperity, and fulfillment of public interest if the private sector can't fulfill. For this category, the budget comes from revenues on public property, such as zakat and taxation. Second, state spending that comes from the law through ijtihad decision to solve of issue new. The budget is used to uphold the principles of public welfare, e.g. in the interests of environmental conservation, scientific research, investment, and fulfillment of national stability. Third, public expenditure as a liability of state officials established through the institution of shura' (the legislature). In this case, the government is providing clean water, electricity, postal services, and others. 
Wagner (in Rossen \& Gayer, 2008) explains that public expenditure for government activities that are always increasing. The tendency of increasing public expenditure by Wagner called the "law of ever increasing state activities", or the "law of the ever increasing needs of the state". Thus, an increase in the form of activities and needs of the government, which has links with the duties and functions of government, and the use of economic resources by the government.

The Law of Wagner by Musgrave and Musgrave (1987), known as "the law of growing public expenditures" or "law increasing government spending." The increase in public expenditure was caused by the provision of collective goods is increasing as well. Ibrahim Yusuf (1982) and Abdul Wahid (1971) asserts that public expenditure must pay attention to the principles which include the use of the budget and meet the needs of the public.

Thus, in the early days of public expenditure to be one of the main requirements for Muslims, such as public expenditure for purposes of war. Abu Ubaid (1986) confirms that the government's policy on public financial resources allocated to public expenditures or other general expenses was based on the norms and principles of shariah and the events there. In fact, the Islamic financial system more broadly to include public expenditure which is becoming a habit in economic and social development when it assumes that public expenditure is an activity that always increases with the increase in production, an increase in government revenue, and the absence of public goods for consumption activities.

\section{Discussion}

In Islamic economics, public expenditure in the public interest based on the principles of rational management of expenditure budget. Budgets were developed in accordance with public revenues derived from the public and private sectors and then distributed to the various categories of expenditure. Thus, the principle of the budget is the income available to determine the amount of public expenditure. Public expenditure is determined by the amount of income available from the sources of revenue available. Budget usually surplus or at least a balanced budget.

The budget system in modern states just the opposite. Estimated public expenditure are prepared and then found a way to raise the budget by financial manipulations required by different types of taxes and public revenue sources in order to meet the balance of revenue and expenditure. This resulted, public expenditure is very high despite the scarcity of resources. As a result, the budget deficit will be financed through internal and external borrowing, printing currency, and so forth, so that eventually lead to inflation, recession, and even economic depression.

The theory of public expenditure in Islamic economics cored their government's role in meeting the needs of society through the development programs planned and programmed systemically. Revenue from charity, for example, do not become part of the general budget, because the benefits have been established and are clearly stated in the Quran, as in the surah at-Tawbah verse 60. Public revenue derived from zakat will be positioned on a separate source of funds and distributed for specific purposes, namely eight (8) groups of recipients.

In the management of zakat, as suggested by Abu Ubaid (1986), the government has the policy to distribute it, including alleviating poverty. Zakat should be distributed in the area who compiled. Budget transfers originating from zakat, from one area to another is not allowed unless all recipient groups in the region have received adequately. Mawardi (1996) states that if a part of all the groups of recipients exceeds their needs, the rest is distributed to the recipient that is in the nearby area. Actually, the distribution of zakat in the same place would reduce the social envy of the poor against the wealth of the rich, creating a sense of social responsibility, and foster social awareness among the rich against the poor in the region.

Aspects of the distribution of zakat can be compared with the distribution of the tax being undertaken by many countries. Initial thoughts about the principles of taxation, such as expressed by Roncaglia (2006) and Moran (in Martin, 2009), usually refers to the opinion of Adam Smith (1977) on "canons of taxation". The principles of public expenditure may be called "canons of public expenditure." In the public expenditure, as confirmed Rossen and Gayer (2008), there are seven principles that need to be considered in its management, as detailed below.

Table 4. Principles of Taxation According to Adam Smith 


\begin{tabular}{|c|c|c|}
\hline No & $\begin{array}{l}\text { Principles of } \\
\text { Taxation }\end{array}$ & Description \\
\hline 1 & Morality & $\begin{array}{l}\text { The principle of morality includes religious values, social ethics, customs, } \\
\text { and culture are an important consideration in the management of } \\
\text { government spending. }\end{array}$ \\
\hline 2 & Nationalities & $\begin{array}{l}\text { Government spending as the realization or implementation of the } \\
\text { functions of government in achieving national goals, especially for the } \\
\text { benefit of society and the nation in creating prosperity. }\end{array}$ \\
\hline 3 & Populist & $\begin{array}{l}\text { The government in carrying out its duties and functions should be in } \\
\text { harmony with the principles of sovereignty of the people (democracy). } \\
\text { Thus, the public finance expenditure by the government, not only } \\
\text { obtained approval organ of the sovereignty of the people but also } \\
\text { implemented for the benefit of the people. }\end{array}$ \\
\hline 4 & $\begin{array}{l}\text { Efficiency \& } \\
\text { Effectiveness }\end{array}$ & $\begin{array}{l}\text { All the actions of the government in managing the budget and perform } \\
\text { the functions of public expenditure must consider the level of efficiency } \\
\text { and effectiveness. }\end{array}$ \\
\hline 5 & Functional & $\begin{array}{l}\text { Governments and institutions associated with the function of public } \\
\text { expenditures in carrying out the task should be in accordance with the } \\
\text { position and authority of its positions. }\end{array}$ \\
\hline 6 & Development & $\begin{array}{l}\text { Public finance expenditure by the changes and the dynamics of society in } \\
\text { line with the level of progress achieved. This aspect can lead to the } \\
\text { creation of financial distribution accuracy and equitably to people }\end{array}$ \\
\hline 7 & $\begin{array}{l}\text { Balance } \\
\text { Justice }\end{array}$ & $\begin{array}{l}\text { This principle was the starting point in creating a prosperous community } \\
\text { life. }\end{array}$ \\
\hline
\end{tabular}

Public expenditure can not be separated from the political aspects of the economy. Due and Friedlander (1981) asserts that the optimal efficiency in the use of resources, not just about the production of the government alone, but also the production of private parties. As for the politics of public expenditure is done by considering that the public expenditure policies have a goal, so it does not reduce the motivation to work. Thus, it can encourage the achievement of maximum production efficiency, or achieve optimal allocation of productive forces apart.

Political public expenditure should also be run so that the marginal social benefit from the production of each commodity must be equal to the marginal social cost the resulting from the commodity. Spending on goods by the government should have considered whether the results of the marginal public expenditure equals marginal sacrifice by private parties. Meade (in Due \& Friedlaender, 1981) states that trade and welfare to be causal with optimal allocation of productive forces or the best use of economic resources. While Allen \& Brownlee (in Due \& Friedlaender, 1981), calling it the best allocation of resources the optimum production of economic resources; political and public expenditure is done in such a way so as to achieve full employment and full capacity which means it has achieved employment of all factors units.

In the Islamic economic system, the distribution of the budget is managed by the existing government's financial condition and distributed in accordance with the objectives that have been planned. Mawardi (1996) states that the responsibilities of financial institutions in the form of distribution of the state budget for the benefit of society. The function of public expenditure can be divided into two. First, public expenditure must be financed by the government, including the responsibilities reserved for the values it receives, i.e. for salaries of employees and soldiers, weapons procurement, and compensation. Because of this responsibility as opposed to the value received, the government should set the rules. Implementation of the responsibility it raises costs provided by the state.

The second category of public expenditure that has been set on grants for the public interest. Mawardi (1996) argues that the implementation of this type of responsibility with regard to the 
existence of funds in the state treasury. If there are sufficient funds in the state treasury, public interest responsibilities to be fulfilled. However, if there are no funds, this responsibility can be charged to the community as a social obligation (fardh kifayah). In other words, the management of public expenditure aimed at creating public welfare. Public needs to be the first principle of public expenditure funded by the government itself, or indirectly financed by a rich society.

Abu Yusuf (1979), Yahya (1979) and Abu Ubaid (1986) found that most fundamental role of government is the protection of the public interest. Therefore, Masud (1995) asserts that the concept is associated with increased social and material welfare of society. According to the definition of "public interest", the function of public expenditure into broad and flexible. Consequently, public expenditure has a broad scope is limited by the principle of public interest.

For the purposes of public welfare, Muslim jurists have given details relating to the management functions of public expenditure into social obligations based indicators of public interest. For example, Mawardi (1996) argues that defense, fulfilling the needs of water, and roads are social duties. Other jurists, Nawawi (1343) asserts that the social obligations that include the elimination of poverty by direct assistance, such as food and clothing. According to Ibn Hazm (1347), meeting the needs of the poor is the responsibility of the rich in society, such as food, clothing, and home. For Ghazali (2003), the government is responsible for helping the poor when there are food scarcity and the high price of goods. Thus, the government is obliged to manage the budget for various functions to the public welfare.

\section{Conclusion}

Management of public expenditure can be assessed in Law of Republic of Indonesia Number 38 The year 2017 on States Budget 2017. The application of Indonesian based distribution system that includes central government expenditure by function, organizations and programs, transfers to the regions, and the village fund. Publix expenditure aimed at achieving the goals of development, including through efforts to spur economic growth and uneven quality, reduce poverty, reduce unemployment and control inflation. In management, the government will also continue to sharpen the efficiency and effectiveness of central government expenditure in order to improve the quality of public expenditure.

In Islamic economics, public expenditure is used to meet the needs of the public based on the principles of public interest. This public expenditure as an effective tool to divert economic resources and increase the income of society as a whole. This public expenditure related to the government's role in carrying out its functions, such as setting harmonious religious life, law enforcement, society protection, fulfillment of basic needs, financial administration, and development. This function is focused on people's lives embodiment prosperous.

Conflicts of Interest: The author declare no conflict of interest.

\section{References}

1. Abd al-Wahid, M. Al-Mal fi al-Islam; Majma' al-Buhuts al-Islamiyah: Kairo, 1971.

2. Abu Yusuf. Kitab al-Kharaj; Dar al-Ma'arif: Beirut, 1979.

3. Al-Nawawi. Minhaj al-Thalibin wa 'Umdah al-Muftin; Dar al-Ihya' al-Kutub al-'Arabiyah: Mesir, $1343 \mathrm{H}$.

4. Atkinson, A.B. \& Stiglitz, J.E. Lectures in Public Economics; Mac-Graw Hill: New York, 1980. Available at: $h$ ttp://press.princeton.edu/titles/10493.html

5. Backhaus, J.G. \& Wagner, R.E. The Cameralists: A public choice perspective. Public Choice. 1987, 53, 3-20. DOI: 10.1007/BF00115651. Available at: https://link.springer.com/article/10.1007/BF00115651. 
6. Bird, R.M. Intergovernmental Fiscal Relations in Latin America: Policy Design and Policy Outcomes; Inter American Development Bank: Washington DC., 2001. Available at: http://bivica.org/upload/politica-fiscal.pdf.

7. Biyuni, Sh. Al-Fikr al-Siyasi 'inda Mawardi; Dar al-Tsaqafah li al-Nashr wa al-Tauzi': Cairo, 1983.

8. Buchanan, J.M. \& Musgrave, R.A. Public Finance and Public Choice: Two Contrasting Visions of the State; MIT Press: Cambridge, Mass., 1999. Available at: https://ideas.repec.org/b/mtp/titles/0262024624.html

9. Due, J.F. \& Friedlaender, A.F. Government Finance; Richard D. Irwin, Inc.: New York, 1981. Available https://scholar.google.com/scholar?q=Due\%2C+J.F.+\%26+Friedlaender\%2C+A.F.+\%281981\%29.+ Government+Finance.Ebtn $G=\mathcal{E} h l=i d \mathcal{E} a s_{-} s d t=0 \% 2 C 5$.

10. Foster, M. \& Fozzard, A. Aid and Public Expenditure: A Guide; Overseas Development Institute: London SE1 7JD, $2000 . \quad$ Available at: http://citeseerx.ist.psu.edu/viewdoc/download?doi=10.1.1.506.8484\&rep=rep1Etype=pdf.

11. Ghazali, A.H. Ihya' 'Ulum al-Din; Dar al-Nahdhah: Beirut, 1998.

12. Ghazali, A.H. Al-Tibr al-Masbuk fi Nashihah al-Muluk; al-Mathba'ah al-Khairiyah: Mesir, 2003.

13. Gramlich, E.M. Benefit-cost Analysis of Government Programs; Prentice-Hill: Englewood Cliffs, N.J., 1981. Available at: http://www.encyclopedia.com/arts/educational-magazines/gramlichedward-martin-1939

14. Ibn Hazm. Al-Muhalla; Mathba'ah al-Nahdhah: Mesir, 1347.

15. Ibn Taymiyah. Majmu' Fatawa; Mathabi' al-Riyad: Riyadh, 1963.

16. Ibrahim Yusuf, Yusuf. Muhadharah fi Tarikh al-Fikr al-Iqtishadi al-Islami: Jami'ah al-Azhar: Mesir, 1982.

17. Johansen, L. Some notes on the Lindahl theory of determinations of public expenditure. International Economics Review. 1963, 4, 346-358. DOI: 10.2307/2525312. Available at: http://www.jstor.org/stable/2525312.

18. Kahf, M. (ed.). Lessons in Islamic Economic; IDB-IRTI: Jeddah, 1998.

19. Kahf, M. (ed.). Al-Siyasah al-Iqtishadiyah fi Itsar al-Nidzami al-Islami; Shirkah al-Madinah alMunawwarah: Madinah, 2001.

20. Katabi, G.K. al-Kharaj Mundhu al-Fath al-Islami hatta Awasith al-Qarn al-Thalith al-Hijri: alMumarasah wa-al-Nadzriyah; Huquq al-Thaba' wa-al-Nashr: Beirut, 1997.

21. Kayaalp, O. The National Element in the Development of Fiscal Theory; Palgrave Macmillan: New York, 2004. Available at:http://www.worldcat.org/oclc/244654316

22. Lindahl, Erich. Die Gerechtiggkeit der Besteuerung. Lund, 1919. Available at: http://img.kb.dk/tidsskriftdk/pdf/nto/nto_3rk-PDF/nto_3rk_0029_88420.pdf.

23. Masud, M.K. Syathibi's Philosoph of Islamic Law; Islamic Research Institute: Islamabad, 1995.

24. Mawardi. Adab al-Dunya wa al-Din; Dar al-Fikr: Beirut, 1995.

25. Mawardi. Ahkam al-Sulthaniyah. Dar al-Fikr: Beirut, 1996.

26. McGuire, M.C. \& Aaron, H. Efficiency and equity in the optimal supply of public good. Review of Economics and Statistics. 1969, 51, 31-39. DOI: 10.2307/1926945. Available at: http://www.jstor.org/stable/1926945.

27. Ministry of Finance of the Republic Indonesia. Law of The Republic of Indonesia Number 18 The Year 2016 about States Budget 2017; Ministry of Finance: Jakarta, 2016.

28. Moran, Beverly. Adam Smith and the search for an ideal tax system. In Isaac William Martin, et al. (eds.). The New Fiscal Sociology: Taxation in Comparative and Historical Perspective; Cambridge University Press: New York, 2009. Available at: http://taxprof.typepad.com/taxprof_blog/files/Moran.pdf

29. Musgrave, R.A. \& Musgrave, P.B. Public Finance in Theory and Practice; McGraw Hill: Singapore, 1987. Available at: https://trove.nla.gov.au/work/9097058

30. Musgrave, R.A. \& Peacock, A.T. (eds.). Classics in the Theory of Public Finance; Macmillan: London, 1958. Available at: www.palgrave.com/us/book/9780312121624. 
31. Musgrave, R.A. The Theory of Public Finance; McGraw-Hill: New York, 1959. Available at: https://www.jstor.org/stable/2227672.

32. Peacock, A.T. \& Wiseman, J. The Growth of Public Expenditure in the United Kingdom; George Allen \& Unwin: London, 1967. Available at: www.nber.org/chapters/c2302.pdf.

33. Pigau, A.C. The Economic Welfare; Macmillan: London, 1920. Available at: www.econlib.org/library/NPDBooks/Pigou/pgEW.html.

34. Pigau, A.C. A Study in Public Finance; Macmillan: London, 1947. Available at: http://www.new.dli.ernet.in/handle/2015/190007.

35. Qardhawi, Y. Fiqh al-Zakah; Mu'assasah al-Risalah: Beirut, 1984.

36. Roncaglia, Alessandro. The Wealth of Ideas: a History of Economic Thought; Cambridge University Press: New York, $2006 . \quad$ Available at: www.journals.uchicago.edu/doi/pdf/10.1086/605136.

37. Rossen, H.S. \& Gayer, T. Public Finance; McGraw-Hill: New York, 2008. Available at: www.fintp.hr/upload/files/ftp/2008/1/primorac.pdf.

38. Samuelson, R.J.. Pure theory of public expenditure and taxation. In Margolis, J. \& Guitton, H. (eds.). Public Economics; St. Martin Press: New York, 1969. Available at: https://courses.cit.cornell.edu/econ335/out/samuelson_pure.pdf

39. Siddiqi, S. A. Public Finance in Islam; Shah Muhammad Ashraf Publishing: Lahore, 1962. Available at: http://sfx.bibbvb.delsfx_ubm? sid=google\&auinit=SAEaulast=SiddiquiEtitle $=$ Public + finance+in+Islam $\& g e n r e=b o$ okEisbn=8174351361Edate $=2007$.

40. Siddiqie, M.N. Teaching Public Finance in Islamic Perspective; KAU-Centre for Research in Islamic Economics: Jeddah, 1992. Available at: http://citeseerx.ist.psu.edu/viewdoc/download?doi=10.1.1.515.9071Erep=rep1Etype=pdf.

41. Smith, Adam. The Wealth of Nations; J.M. Dens and Sons: London, 1977. Availabe at: https://www.marxists.org/reference/archive/smith-adam/works/wealth-of-nations/.

42. Soepangat, E. \& Gaol, H. L. Introduction of Public Finance; Gramedia Pustaka Utama \& STIE Perbanas: Jakarta, 1991.

43. Syatibi. al-Muwafaqat; Dar al-Fikr: Beirut, 1995.

44. Wagner \& Weber. Wagner's law, fiscal institutions, and the growth of government. National Tax Journal, 1977, 30, 59-68. Available at: http://www.jstor.org/stable/41862113.

45. Yahya bin Adam. Kitab al-Kharaj; Dar al-Ma'arif: Beirut, 1979. 